\title{
Prikazi
}

https://doi.org/10.22210/suvlin.2019.087.09

\section{Rječnici kroz prizmu kritičke lingvistike. Vojko Gorjanc, Nije rečnik za seljaka, Biblioteka XX vek, Beograd, 2017.}

Vojko Gorjanc redoviti je profesor Odsjeka za prevođenje Filozofskog fakulteta Sveučilišta u Ljubljani. Također, voditelj je jednog od središnjih istraživačkih nacionalnih programa na području slovenistike pod nazivom »Slovenski jezik - osnovna, kontrastivna i primijenjena istraživanja«, a u posljednjih je par godina autor aktivno uključen i u rad novog sveučilišnog Centra za jezične resurse i tehnologiju (http://www.cvjt.si). Kao što će biti vidljivo kroz prikaz koji slijedi, uži interesi autora sežu u područja sociolingvistike, tekstne lingvistike, kritičke analize diskursa (KDA), što autor nadopunjuje koristeći se metodologijom korpusne lingvistike. Trenutno je njegov glavni fokus usmjeren prema jeziku i jezičnim ideologijama, odnosima moći u diskursu i jezičnoj medijatiziranosti u procesu prevođenja.

Nakon prve dvije autorske knjige, Uvod u korpusno jezikoslovlje (2005) te knjige napisane u suautorstvu s Alenkom Morel Skupnostno tolmačenje: slovenččina v medkulturni komunikaciji (2016), Gorjanc u studiji Nije rečnik za seljaka (2017) donosi uvid u leksikografiju iz perspektive kritičkog jezikoslovlja.

Autor kao polazište u knjizi uzima osnovne premise i metodološki pristup kritičke analize diskursa, a zbog problematike o kojoj raspravlja (heteronormativnost, politička korektnost, ideologizacija rječnika, jezična elita vs. jezična margina, dijalektika društva i normativnog jezikoslovlja) uvodi nas u područje queer lingvistike ${ }^{1}$ i kritičke leksikografije.

Knjigu je u izdanju beogradskog nakladnika Biblioteka XX vek sa slovenskog na srpski prevela Majda Moličnik. Iako je strukturirana u osam različitih poglavlja, nije preopsežnog karaktera te može poslužiti kao uvod u neke od tema i poddisciplina kritičkog jezikoslovlja. Autor stoga u prvom poglavlju pruža uvod u vlastiti teorijski okvir osvrćući se na osnove poststrukturalističke misli, kritičke lingvistike odnosno njezinih suvremenijih izdanaka u obliku kritičke analize diskursa. Gorjanc spomenute pristupe primjenjuje na problematiku rodnih ideologija: LGBTQ zajednice i feminizma te manjinskih i marginaliziranih društvenih skupina (poput Roma) u leksikografiji. Drugo poglavlje posvećeno je standardnojezičnoj ideologiji, dok nas treće poglavlje priprema za kvalitativnu, kritičku analizu slovenskih jednojezičnih rječnika koja slijedi u narednim trima poglavljima. Četvrti se dio knjige bavi heteronormativnošću rječničkih opisa, da bi se u petom poglavlju to nadogradilo propitivanjem reprezentativnosti korpusa kao i propitivanjem ideologiziranosti/objektivnosti leksikografa pri odabiru leksičkih jedinica. U šestom poglavlju

1 Ponekad nazivane i jezikoslovljem boje lavande (engl. lavender linguistics). 
autor raspravlja o laičkom shvaćanju rječnika te o njihovu utjecaju na društvenu stvarnost, dok se posljednjim dvama dijelovima studije okreće prema budućnosti leksikografije koja se sve više orijentira digitalizaciji, dostupnosti, interdisciplinarnosti i korisniku.

Iako se knjiga bavi slovenskom leksikografijom, autorov pristup istovremeno pruža opću sliku važnosti i uloge jezika u suvremenim svjetskim društvima te daje uvid u primijenjenu lingvistiku čitavoga južnoslavenskog kulturnog prostora, njezine probleme i njezine trendove. Iz navedenih razloga kao štivo može biti zanimljiva mnogo široj zajednici stručnjaka, ali i laika.

S obzirom na to da se kritička analiza diskursa kao i queer lingvistika rađaju u okrilju poststrukturalističke misli, Gorjanc čitatelja usmjerava prema njezinim osnovnim pojmovima poput koncepta dekonstrukcije, važnosti konteksta znanosti (kulturnog, sociopolitičkog, vremenskog) i njezina predmeta te prema razotkrivanju i osvještavanju pozadinskih ideologija na svim društvenim razinama. Ne bi li bolje razjasnio vlastito istraživačko polazište, autor smješta poststrukturalističku lingvistiku u kontekst trendova akademske zajednice šire regije i Europe. Ovdje se ističe dominacija strukturalne lingvistike unutar akademske zajednice, posebice $u$ domeni nacionalnih filologija i nacionalnih humanističkih znanosti općenito (Gorjanc 2017: 11). Naime, autor time upućuje epistemološku kritiku struci, govoreći da je strukturalna lingvistika s pozicije moći uglavnom procjenjivala i vrednovala lingvističke aktivnosti u društvu, u velikoj mjeri odbijala interdisciplinarne pristupe i često davala do znanja da sve što izlazi iz okvira dijalektologije, normativistike i tradicionalno shvaćene morfologije ili sintakse, nije lingvistika (Gorjanc 2017:11). Takve podjele jezikoslovlja na ono »pravo « $\mathrm{i}$ »nepravo « nisu novost, ali izvrsno oslikavaju osnovni predmet kritičke analize diskursa, a to je dinamika društvene moći, društvena nejednakost i njezina reprodukcija kroz diskurs.

»Da bi iz oblasti relevantnog lingvističkog diskursa uklonili lingviste sa poststrukturalističkim istraživačkim polazištem, pripadnici tradicionalne lingvistike zasnovane na strukturalizmu, koriste nazive kao što su npr. sociolozi, jezički tehnolozi idr.«(Gorjanc 2017:12)

Uz makroperspektivu, Gorjanc govori i o mikrosociološkim čimbenicima istraživačkih sredina osvrćući se na pojedinca istraživača i problem objektivnosti istraživača. Uvodeći pojam ideologije kao jedan od ključnih pojmova KAD-a, autor se zapravo referira na pojavu koju Škiljan (1991: 23) naziva ideološkim filtrom. Ukratko, svatko od nas djeluje u okrilju vlastitih ideologija. One se zasnivaju na relativno stabilnim stavovima, uvjerenjima i vrijednostima na temelju kojih donosimo odluke. Na taj način svjesno ili podsvjesno krojimo vlastito djelovanje. Naše je iskustvo također ideologizirano jer iskustveni filtar prima već »iskrivljene« (tj. ideologizirane) informacije. Stoga da bismo bili što objektivnijima, potrebno je osvijestiti vlastite ideologije i u iskazima (diskursu) biti što korektnijima. No ovdje se primjećuje jedna od temeljnih premisa poststrukturalizma i KAD-a, a to je pretpostavka 
da istinski objektivna, apsolutno objektivna spoznaja nije moguća (pa tako ni ona znanstvena).

U potpoglavlju naslovljenome »Kritička lingvistika i kritička analiza diskursa» čitatelju je pružen kratak i ponešto selektivan pregled područja KAD-a. Gorjanc pritom izdvaja osnovne pojmove i neke od tema područja, a naglasak stavlja na rad Normana Fairclougha (predstavnika dijalektičko-relacijskog pristupa KAD-a) i Teuna van Dijka (predstavnika sociokognitivnog pristupa). Zanimljivo je da se nigdje u uvodno-teorijskom dijelu ne spominje korpusnolingvistički pristup i KAD, primjerice istraživanja Baker i McEnery 2005, Baker et al. 2007, Cotterill 2001, Fairclough 2000a itd. (Mautner 2009), posebice zbog tematike prijašnjih autorovih radova i njezine metodološke primjenjivosti unutar leksikografije. Također, činjenica jest da Gorjanc kroz vlastitu analizu u kasnijim poglavljima implementira korpusnolingvističke metode, stoga ne bi bilo na odmet da se na to osvrnuo, barem u smislu komplementarnosti i nadopunjavanja kvalitativnih podataka koje pruža KAD s kvantitativnim podatcima korpusnog jezikoslovlja.

Također, autor nam ne daje uvid u oblast kritičke lingvistike per se, iako je tako sugerirano naslovom odlomka. Pretpostavljamo da je to zato što ga on sam upotrebljava kao krovni pojam, tj. kao područje koje obuhvaća sve kritičke pristupe unutar lingvistike (pa tako i KAD i queer lingvistiku). Takvo shvaćanje u osnovi nije pogrešno, no kritička lingvistika mnogo je više od toga. Ona je i kronološka prethodnica i izvorišna točka kritičke analize diskursa (Althusser, Adorno, Horkheimer), iznimno je interdisciplinarna, no osim kritičkoj lingvistici KAD mnogo duguje i sociolingvističkim istraživanjima. To područje odlikuju dva velika pravca s prominentnim predstavnicima: korelacijski pristup (Labov, Hymes, Gumpertz) i tzv. perspektiva izbora predstavljena Hallidayevom sistemskom funkcionalnom gramatikom (Kress 2001). Stoga smatramo da je potrebno pojašnjenje važnosti kritičke lingvistike i kroz njezin razvojni put: u odnosu na strukturalizam kao dominantnu znanstvenu paradigmu 20. stoljeća s jedne strane te važnost njezina surađivanja i »stapanja« s drugim disciplinama (npr. sociologijom, filozofijom, psihologijom, antropologijom, pragmatikom, semiotikom itd.) s druge strane. Time bi se lakše argumentirala njezina opravdanost, nužnost i logičnost u svijetu ideologizirane jezične upotrebe.

U sljedećem podnaslovu autor nešto ozbiljnije pristupa grani jezikoslovlja novijeg vijeka, domeni queer lingvistike, koja prema Kochu (2008: 38-39):

"... zagovara interdisciplinarni pristup u okviru poststrukturalističkih kritičkih teorija kada se radi o pitanju diskurzivno kreiranih identiteta roda i seksualnosti i analizom diskurzivnih praksi želi da doprinese shvatanju diskurzivne konstrukcije kategorija identiteta kao ideoloških društvenih konstrukata, obeleženih heteronormativnošću."(Gorjanc 2017:17)

Ovdje je pružen dobar uvid u problematiku i glavne teme područja, što je pohvalno zbog općenitog manjka domaće i regionalne literature iz queer jezikoslovlja i 
osvježavajuće jer ide ususret aktualnim društvenim problemima i njihovim potencijalnim rješenjima.

Nakon queer lingvistike Gorjanc se vraća u oblast leksikografije, rječnika i korisnika tih rječnika, no iz kritičke perspektive, i time zaključuje prvi dio knjige.

"Ako je u rečničkom opisu kodirana diskriminacija kao norma, rečnik može da postane argument za njeno očuvanje ili uspostavljanje, čime postaje zanimljiv i za oblast kritičke analize.« Gorjanc (2017: 25)

U sljedećem poglavlju, pod nazivom »Ideologija standardnog jezika«, čitatelj biva upoznat $s$ drugim licem standardnog jezika. Upoznaje se s odnosom jezika i politike, procesom i važnošću jezičnog normiranja, društvenim elitama i jezičnim ideološkim debatama (Blommaert 1999). Autor ovdje također raspravlja o jezičnim intervencijama poput ideologije političke korektnosti ili pak ideologije jezičnog purizma. Poglavlje se zaključuje sljedećom rečenicom:

»Karakteristika standardnojezičke kulture jeste upravo nepostavljanje pitanja o adekvatnosti jezičkih opisa, već neopozivo verovanje autoritetu, čime se (...) namerno ili nehotice promovišu tradicija i konzervativne društvene vrednosti.« (Gorjanc 2017: 39)

Posljednje poglavlje teorijskog uvoda u studiju, naslova »Rečnici nisu nevini«, govori o ideologiziranosti rječnika i utjecaju tih istih ideologija na društvenu stvarnost. Autor naposljetku ovdje predstavlja svoj krajnji cilj, a to je otkriti principe rječničkog opisa koji upućuju na neneutralnost, i opisa i rječničkih pristupa. To u narednim trima poglavljima vidimo u primjeni, pri čemu Gorjanc promatra i eksplicitne ideologije autora rječnika na razini rečenične definicije i one prikrivene, $s$ pomoću ideologiziranih primjera jezične upotrebe.

Prvo poglavlje posvećeno analizi (»Homoseksualnost, egzibicionizam i druge perverznosti«) nastoji utvrditi kako institucionalizirana ideologija univerzalnosti heteroseksualnosti postaje normom našega jezičnog ponašanja. $S$ obzirom na to, fokus je stavljen na problematiku heteronormativnosti i na ideološku poziciju leksikografa te je pruženo obilje primjera. Autor taj dio vlastite analize zaključuje sljedećim:

»Kod tekstova, povezanih sa homoseksualnošću, rešenja u RSKJ ne samo da institucionaliziraju ideologiju univerzalnosti heteroseksualnosti, već heteroseksualnosti postavljaju kao normu, a homoseksualnost ne samo kao odstupanje od nje, već kao devijantnost." (Gorjanc 2017: 74)

Gorjanc navodi da se već u RSKJ-u $2^{2}$ na homoseksualnost više ne gleda kao na devijantnost, pri čemu ističe implementaciju boljih primjera u rječnik, suradnju s pripadnicima LGBTQ zajednice pri formiranju rječnika i važnost konteksta vremena.

Sljedeća se analiza odnosi na feminističke teme unutar leksikografije, tj. razmatra se kako su žene prikazivane u rječničkim opisima, kako je do toga došlo i zalaže se za dosljedno provođenje korpusnolingvističkog pristupa u leksikografiji.

2 RSKJ akronim je za »Rječnik slovenskoga književnog jezika«. 
Analiza RSKJ-a otkriva muškost kao neutralan ili uglavnom pozitivan društveni fenomen, a ženskost kao odstupanje od društvene norme, naročito kada se radi o pitanju opisa seksualnih aktivnosti (Gorjanc 2017: 93). Autor ovdje naglašava kako je izbor primjera upotrebe najčešće društvena stvarnost koju vide leksikografi, tj. ideološki izbor leksikografa, ali je također posljedica nereprezentativnosti građe (izbor iz literarne fikcije umjesto stvarnog konteksta jezične upotrebe) i rezultat duha vremena.

Posljednje analitičko poglavlje bavi se problematikom etničkih i jezičnih manjina koje obično bivaju marginaliziranima i deprivilegiranima. To je često potpomognuto i reproducirano institucionaliziranim društvenim praksama, pa tako i leksikografskim radom, a posljedice ima u domeni pravosuđa te politike, pa time i svakodnevice. Autor se ovdje konkretno osvrće na Rome i njihovo prikazivanje unutar slovenske leksikografije, percepciju Roma od strane elita i perpetuiranje nejednakosti te produbljivanje jaza između margine i samog vrha. Autor napominje da je za rješavanje takve situacije nužno izmijeniti pristup rječničkom opisu, koji bi trebao sadržavati više pragmatičkih informacija koje korisnika upućuju na stvarni kontekst upotrebe i time otklanjaju višeznačnosti, nejasnoće i mogućnost manipulacije informacijama.

Knjiga se zaključuje okretanjem prema budućnosti. Autor se ovdje zalaže za rječničke opise usmjerene korisniku, no istovremeno je svjestan interesa lingvističkih i leksikografskih krugova koji bi time izgubili privilegiranu poziciju moći prosuđivanja o jeziku i određivanja kruga standardnojezičnih elita. Gorjanc također pruža podatke o očekivanjima mlađe generacije korisnika rječnika dobivene na temelju anketa, iz čega saznajemo da je za tu skupinu rječnik dinamička pojava koja prati promjene u jeziku i stalno se ažurira, prikazuje stvarnu upotrebu, dostupan je i praktičan (npr. jednostavan, brz i intuitivan, preglednog sučelja, jednostavne navigacije, povezan s korpusom, posjeduje zvučni zapis o izgovoru itd.). Dakle, zaokret prema digitalizaciji rječnika sa sobom je donio sasvim drugačije strukturiranje podataka, neograničenost u količini podataka i mogućnost aktivnog sudjelovanja u stvaranju rječnika.

Za sam kraj autor donosi još jednu aktualnu temu - goruće pitanje otvorenog pristupa (engl. open access) novim znanjima (pa tako i leksikografskim podacima). ${ }^{3}$ Sve se iznimno dobro sažima u sljedećem citatu:

»Više od dvadeset godina nastojanje da naučne objave budu slobodno dostupne, ima svoje svetle i tamne periode. Njegovi inicijatori su akademski učitelji i istraživači, univerzitetske biblioteke i naučna ministarstva država /.../, ali koče ga akteri koji od trenutne trgovine naučnim tekstovima imaju najviše koristi, a to su izdavačke kuće, koje izdaju časopise i sa dodanom vrednošću, indeksom citata, nude koristan servis za vrednovanje naučnih objava.«(Hladnik 2014)

3 Za stanje o otvorenom pristupu u Hrvatskoj vidi: Macan, Bojan (2018). Osiguravanje otvorenog pristupa znanstvenim publikacijama - tko, što i kako?. U: Hebrang Grgić, I. (ur.) Otvorenost u znanosti i visokom obrazovanju. Zagreb: Školska knjiga, str. 59-79. 
Naposljetku, možemo donijeti sud da se ova knjiga može iščitavati u nekoliko slojeva, tj. na nekoliko različitih razina, stoga bismo je preporučili i laicima i stručnjacima. Laici se $s$ jedne strane zbog zanimljivih primjera mogu dobro zabaviti ovom knjigom i istovremeno saznati nešto novo, tj. dobiti kritički uvid u svijet diskursa kojega su i sami dijelom. S druge strane, iščitavanjem ove studije iz znanstvene perspektive razotkriva se drugi sloj kritike, kritike upućene ne samo leksikografskoj i široj akademskoj zajednici već i cjelokupnom društvu.

\section{Literatura:}

Blommaert, Jan (ur.) (1999). Language Ideological Debates. Berlin; New York: Mouton de Gruyter.

Gorjanc, Vojko (2017). Nije rečnik za seljaka. Beograd: Biblioteka XX vek.

Hladnik, Miran (2014). Nova pisarija: Strokovno pisanje na spletu. Wikiknjiga. https://sl.wikibooks.org/wiki/Nova_pisarija/tisk

Kress, Gunther (2001). From Saussure to Critical Sociolinguistics: The Turn Towards a Social View of Language. Wetherell, Margaret, Stephanie Taylor i Simeon J. Yates, ur. Discourse Theory and Practice: A Reader. London: Sage Publications with The Open University.

Macan, Bojan (2018). Osiguravanje otvorenog pristupa znanstvenim publikacijama - tko, što i kako? Hebrang Grgić, Ivana, ur. Otvorenost u znanosti i visokom obrazovanju. Zagreb: Školska knjiga, str. 59-79.

Mautner, Gerlinde (2009). Checks and Balances: How Corpus Linguistics can Contribute to CDA. Wodak, Ruth i Michael Meyer, ur. Methods of Critical Discourse Analysis, second edition. Los Angeles, etc.: Sage Publications.

Škiljan, Dubravko (1991). Kraj lingvistike? Fragmenti protiv fragmentizacije. Zagreb: SOL.

Jana Jurčević 